\title{
A PRELIMINARY STUDY ON THE AGE AND GROWTH OF THE ARGENTINE, ARGENTINA SPHYRAENA (ACTINOPTERYGII: OSMERIFORMES: ARGENTINIDAE) FROM THE EASTERN ADRIATIC SEA
}

\author{
Josipa FERRI *, Jure BRČIĆ, Frane ŠKELJO, Lidija SRŠEN, and Anja UVODIĆ \\ Department of Marine Studies, University of Split, Split, Croatia
}

\begin{abstract}
Ferri J., Brčić J., Škeljo F., Sršen L., Uvodić A. 2017. A preliminary study on the age and growth of the argentine, Argentina sphyraena (Actinopterygii: Osmeriformes: Argentinidae) from the eastern Adriatic Sea. Acta Ichthyol. Piscat. 47 (4): 365-369.
\end{abstract}

Background. Age determination is a basic step in understanding fish biology and dynamics of fish populations. The only available data on the age and growth of argentine, Argentina sphyraena Linnaeus, 1758, a noncommercially exploited species of the family Argentinidae, was published almost half a century ago. More recent reports are limited to general biological characteristics of $A$. sphyraena so the main goal of our study was to fill a gap by investigating age and growth of the eastern Adriatic population of this fish.

Materials and methods. Samples of the argentine were collected in the eastern Adriatic Sea, during March 2011, using a bottom trawl. We analysed sagittal otolith morphology and morphometry; the age of each fish was determined from the number of growth zones on otoliths and relations between the observed otolith age and otolith morphometrics were constructed using a power model. Mean length-at-age was described using the von Bertalanffy growth model.

Results. Sagittal otoliths of Argentina sphyraena displayed alternating opaque and translucent zones. The maximum observed age was 3 years for both females and males. Females that were $2+$ and $3+$ years old were the most numerous in the sampled population. The estimated values of the von Bertalanffy growth model parameters were: $L_{\infty}=17.57 \mathrm{~cm} ; k=0.40$ year $^{-1} ; t_{0}=-1.39$ years. The age of the argentine can be best predicted from the otolith thickness.

Conclusion. The maximum lengths and ages recorded in this study confirmed that in warmer southern latitudes, Argentina sphyraena attains a smaller maximum size. It should be emphasized that the presented model described the growth of fish ages 1-3 and therefore is probably representative only for younger age groups of argentine.

Keywords: otolith, morphometry, Mediterranean

\section{INTRODUCTION}

The argentine, Argentina sphyraena Linnaeus, 1758, is a small marine nektobenthic species of the family Argentinidae found in the eastern Atlantic, from the northwest Norway to the northern Mauritania including Iceland, Faroe Islands, and Shetland Islands, as well as in the western Mediterranean (Halliday 1969c, Bilge and Gülşahin 2014, Hartel and Orrell 2016). It has a range typical of Mauritanian-Mediterranean-Boreal shelf species, inhabiting depths down to $700 \mathrm{~m}$ (Halliday 1969c, Mytilineou et al. 2005, Politou et al. 2008). It displays shoaling behaviour during the night hours and individual feeding movements during the daylight (Carpentieri et al. 2005). This species of non-commercial importance is usually caught as a bycatch in the commercial trawling (Bilge and Gülşahin 2014).

Information on the population parameters of Argentina sphyraena is scarce, as is the case for many other non- commercially important species. The biology of this fish was studied for the first time in the Clyde Sea area (Scotland) from 1963 through 1966 (Halliday 1969a, 1969b, 1969c). These studies provided a detailed analysis of distribution and population parameters of the argentine, such as age, growth, length-weight relation, annual condition cycle, mortality, reproduction, and feeding. Other reports are limited to the general biological characteristics of the species (Schmidt 1918, Poll 1953, Cohen 1958, 1990, Muus and Nielsen 1999, Petrić et al. 2012, Bilge et al. 2014, Hartel and Orrell 2016) and the data on the relation between sagittal otolith size and fish size of the southern Aegean Sea population (Bilge and Gülşahin 2014).

This study investigates the age and growth of the eastern Adriatic population of the argentine in order to obtain growth parameters and therefore provide better insight into the life history of this species. This is particularly 
important because the only available data on the age and growth of Argentina sphyraena was published almost half a century ago (Halliday 1969a). In this study, fish age was determined by counting annuli in sagittal otoliths and the use of otolith morphometrics as an alternative method of age estimation was evaluated.

\section{MATERIALS AND METHODS}

Samples of the argentine, Argentina sphyraena, were collected with the commercial bottom trawl, during the daytime in March 2011, at depths from 110 to $115 \mathrm{~m}$. The area sampled was the central eastern Adriatic Sea, fishing zone $\mathrm{G}$, between $43^{\circ} 22^{\prime} 49^{\prime \prime} \mathrm{N}, 16^{\circ} 07^{\prime} 94^{\prime \prime} \mathrm{E}$ and $43^{\circ} 12^{\prime} 62^{\prime \prime} \mathrm{N}, 16^{\circ} 18^{\prime} 63^{\prime \prime} \mathrm{E}$. Each fish was measured to the nearest $0.1 \mathrm{~cm}$ total length $\left(L_{\mathrm{T}}\right)$ and weighed to the nearest $0.01 \mathrm{~g}(W)$. Sex was determined by macroscopic analysis of the gonads and sagittal otolith pairs were removed, cleaned, and stored dry for later examination. Length frequency distributions of females and males were compared using the Kolmogorov-Smirnov two-sample test.

Prior to polishing, otoliths were photographed with an Olympus DP-25 digital camera attached to a stereomicroscope. Otolith length $\left(L_{\mathrm{O}}\right)$ and breadth $\left(B_{\mathrm{O}}\right)$ were measured to the nearest $0.01 \mathrm{~mm}$ using Olympus Cell ${ }^{\mathrm{A}}$ Imaging Software. Otolith length was defined as the longest axis between anterior and posterior otolith edge and the otolith breadth as a distance from dorsal to ventral edge taken perpendicular to the length through the otolith focus. Otolith thickness $\left(T_{\mathrm{O}}\right)$ was measured using a digital calliper with a precision of $0.01 \mathrm{~mm}$ and otolith weight $\left(W_{\mathrm{o}}\right)$ was determined to the nearest $0.0001 \mathrm{~g}$. Differences between left and right otoliths were tested by paired $t$-test and ANCOVA was used to test for differences in otolith measures between the sexes. Relations between the fish total length (or weight) and the otolith morphometrics were constructed using the linear model.

The medial face of a single, randomly selected otolith from each pair was polished and photographed with an Olympus DP-25 digital camera attached to a stereo microscope, with reflected light against a dark background. We used images for the age reading because their quality and ability to adjust contrast and brightness made it easier to interpret zoning patterns. The age of each argentine was determined from the number of annuli, knowing that one transparent ring is deposited in their otoliths each year (Halliday 1969a). Two readers carried out the age estimation independently and the relative precision between the two readings was estimated by the index of mean percentage error (IMPE)* (Beamish and Fournier 1981) and the coefficient of variation (CV) (Chang 1982). When the two age readings differed, both readers jointly examined corresponding otolith photographs and agreed on the correct age.

Length-at-age was described by the von Bertalanffy growth model using a non-linear least-square procedure of a Gauss-Newton algorithm. Once the age was determined by counting annual rings, relations between observed otolith age and otolith morphometrics (length, breadth, thickness, and weight) were constructed using a power model since it provided a better fit then the simple linear model.

\section{RESULTS}

A total of 105 specimens of Argentina sphyraena were collected for the age analysis, including 63 females, 28 males, and 14 individuals of undetermined sex (Table 1). Total length of females and males ranged from 10.9 to $16.4 \mathrm{~cm}$ and from 8.9 to $13.5 \mathrm{~cm}$, respectively. Length frequency distributions were significantly different between the sexes (Kolmogorov-Smirnov two-sample test; $P<0.05$ ), with females dominating in the $\geq 14.0 \mathrm{~cm}$ length classes (Fig. 1).

Table 1

Range of total length and weight of Argentina sphyraena sampled in the eastern Adriatic

\begin{tabular}{lcclcc}
\hline \multirow{2}{*}{ Sex } & \multicolumn{2}{c}{ Total length $[\mathrm{cm}]$} & & \multicolumn{2}{c}{ Weight $[\mathrm{g}]$} \\
\cline { 2 - 3 } \cline { 5 - 6 } & Range & Mean $\pm \mathrm{SD}$ & & Range & Mean $\pm \mathrm{SD}$ \\
\hline Females & $10.9-16.4$ & $13.65 \pm 1.339$ & & $8.12-26.84$ & $15.08 \pm 4.439$ \\
Males & $8.9-13.5$ & $11.89 \pm 1.225$ & & $3.60-14.35$ & $9.47 \pm 2.837$ \\
All & $8.8-16.4$ & $12.95 \pm 1.536$ & $3.57-26.84$ & $12.91 \pm 4.692$ \\
specimens & & & & & \\
\hline
\end{tabular}

$\mathrm{SD}=$ standard deviation.

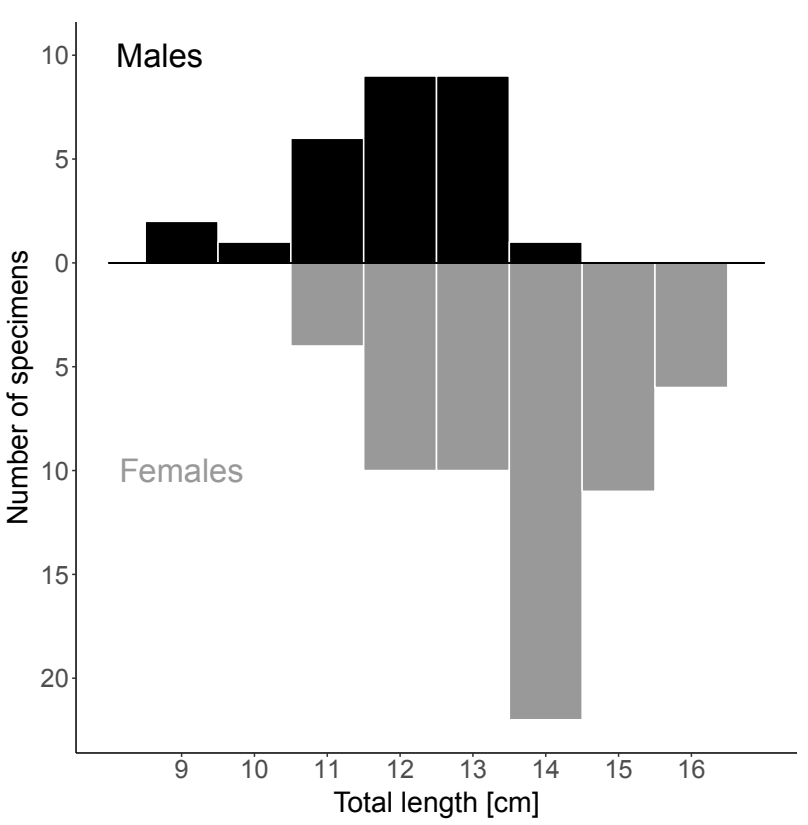

Fig. 1. Length structures of Argentina sphyraena females and males sampled in the eastern Adriatic

Overall otolith shape of the argentine is pentagonal, with irregular posterior and dorsal margins (Fig. 2A). Anterior region is elongate while the posterior is round and the ostium is shorter than cauda. No significant differences in morphometric measures were found between left and 
right otoliths (paired $t$-test, $P>0.05$ for all measures) and between females and males (ANCOVA, $P>0.05$ for all measures), so data were pooled for both sexes and mean values for each otolith pair were used in the further analyses (Table 2). A linear model described relations between the fish total length (or weight) and otolith morphometrics, with high coefficients of determination $(\geq$ 0.580) (Table 3).

Sagittal otoliths displayed well-defined alternating opaque and translucent zones (Fig. 2B). Two independent readers successfully determined age in a way that both readers estimated the same age for 57 fish (54.3\%). For 43 fish (41.0\%) age estimates differed by one year, and for the remaining 5 fish (4.7\%) by two years. The variability indices IAPE and CV were $12.02 \%$ and $17.01 \%$, respectively. The maximum age observed was 3 years for both females and males. Mean lengths ( \pm standard deviation, SD) of one-year-old, two-year-old, and threeyear-old specimens were $10.87 \pm 0.906 \mathrm{~cm}, 13.10 \pm 0.862$ $\mathrm{cm}$, and $14.58 \pm 0.989 \mathrm{~cm}$, respectively. Females were larger than males at all ages and dominant in age classes $2+$ and $3+$.

The von Bertalanffy growth parameters were calculated for all specimens (Table 4). The growth curve for observed lengths-at-age is shown in Fig. 3. Relations

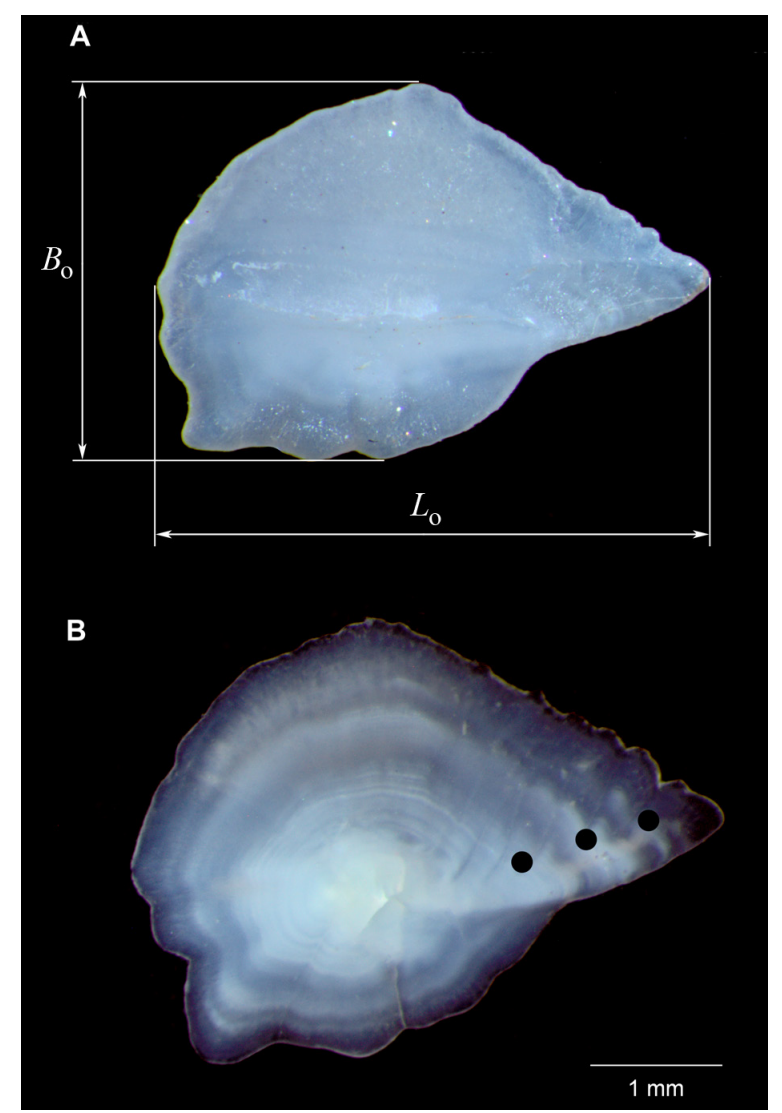

Fig. 2. Sagittal otolith of Argentina sphyraena sampled in the eastern Adriatic (the right otolith with anterior region to the right and dorsal margin to the top (A); $L_{\mathrm{O}}=$ otolith length, $B_{\mathrm{O}}=$ otolith breadth); sagittal otolith of the three-year-old Argentina sphyraena sampled in the eastern Adriatic (B) between otolith morphometrics and observed age are presented in Table 5. A power model explained between $2 \%$ and $50 \%$ of the variation in age.

\section{DISCUSSION}

The maximum lengths and ages recorded in this study were lower than the respective values reported for the northern Iceland $(27.7 \mathrm{~cm}$ standard length, Kotthaus and Krefft 1957), Clyde Sea, Scotland (21.5 cm standard length and 11 years, Halliday 1969a), or the Mediterranean (19.0 cm standard length, Lee 1963; and $18.1 \mathrm{~cm}$ total length, Bilge and Gülşahin 2014). Observed differences among populations may be due to the smaller maximum size of Argentina sphyraena in the warmer southern latitudes compared to those from the northern regions (Halliday

Table 2

Principal otolith parameters of Argentina sphyraena sampled in the eastern Adriatic

\begin{tabular}{ccr}
\hline Parameter & Range & \multicolumn{1}{c}{ Mean $\pm \mathrm{SD}$} \\
\hline$L_{\mathrm{O}}[\mathrm{mm}]$ & $2.82-4.98$ & $4.10 \pm 0.404$ \\
$B_{\mathrm{O}}[\mathrm{mm}]$ & $1.76-3.48$ & $2.76 \pm 0.304$ \\
$T_{\mathrm{O}}[\mathrm{mm}]$ & $0.45-0.85$ & $0.62 \pm 0.083$ \\
$W_{\mathrm{O}}[\mathrm{g}]$ & $0.0057-0.0428$ & $0.0246 \pm 0.011$ \\
\hline
\end{tabular}

$\mathrm{SD}=$ standard deviation; $L_{\mathrm{O}}=$ otolith length, $B_{\mathrm{O}}=$ otolith breadth, $T_{\mathrm{O}}=$ otolith thickness, $W_{\mathrm{O}}=$ otolith weight.

Table 3

Parameters of the linear regression between the total length or weight and the otolith parameters of Argentina sphyraena sampled in the eastern Adriatic

\begin{tabular}{cccc}
\hline Relation & $a$ & $b$ & $R^{2}$ \\
\hline$L_{\mathrm{T}}$ vs. $L_{\mathrm{O}}$ & 1.510 & 0.200 & 0.590 \\
$L_{\mathrm{T}}$ vs. $B_{\mathrm{O}}$ & 0.698 & 0.159 & 0.643 \\
$L_{\mathrm{T}}$ vs. $T_{\mathrm{O}}$ & 0.046 & 0.044 & 0.661 \\
$L_{\mathrm{T}}$ vs. $W_{\mathrm{O}}$ & -0.008 & 0.001 & 0.876 \\
$W$ vs. $L_{\mathrm{O}}$ & 3.263 & 0.065 & 0.583 \\
$W$ vs. $B_{\mathrm{O}}$ & 2.122 & 0.049 & 0.580 \\
$W$ vs. $T_{\mathrm{O}}$ & 0.432 & 0.014 & 0.661 \\
$W$ vs. $W_{\mathrm{O}}$ & 0.002 & 0.0004 & 0.866 \\
\hline
\end{tabular}

$a=$ intercept value, $b=$ regression slope, $R^{2}=$ coefficient of determination; $L_{\mathrm{T}}=$ total length of fish, $W=$ fish weight, $L_{\mathrm{O}}=$ otolith length, $B_{\mathrm{O}}=$ otolith breadth, $T_{\mathrm{O}}=$ otolith thickness, $W_{\mathrm{O}}=$ otolith weight.

Table 4

Von Bertalanffy growth parameters of Argentina sphyraena sampled in the eastern Adriatic

\begin{tabular}{lrl}
\hline \multicolumn{1}{c}{ Parameter } & Value & SE \\
\hline$L_{\infty}[\mathrm{cm}]$ & 17.57 & 2.31 \\
$k$ year $\left.^{-1}\right]$ & 0.40 & 0.20 \\
$t_{0}[$ year $]$ & -1.39 & 0.70 \\
$R^{2}$ & 0.662 & \\
\hline
\end{tabular}

$\mathrm{SE}=$ standard error, $L_{\infty}=$ asymptotic total length, $k=$ growth coefficient, $t_{0}=$ theoretical age at zero length, $R^{2}=$ coefficient of determination. 


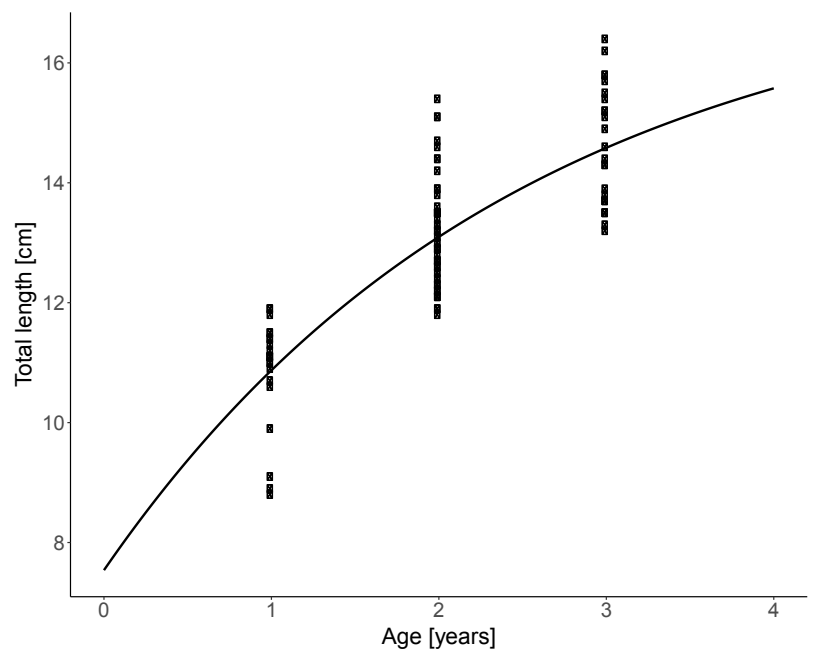

Fig. 3. Observed length-at-age data fitted with the von Bertalanffy growth curve for Argentina sphyraena sampled in the eastern Adriatic

Table 5

Relations between observed otolith age and otolith morphometrics in Argentina sphyraena, sampled in the eastern Adriatic, described using a power model $\left(\right.$ age $=a \cdot$ age estimation predictor $\left.^{b}\right)$

\begin{tabular}{cccc}
\hline Power model & SE $(a)$ & SE $(b)$ & $R^{2}$ \\
\hline age $=0.09 \cdot L_{\mathrm{O}}^{2.20}$ & 0.04 & 0.32 & 0.38 \\
age $=0.18 \cdot B_{\mathrm{O}}^{2.38}$ & 0.05 & 0.37 & 0.49 \\
age $=4.61 \cdot T_{\mathrm{O}}^{1.73}$ & 0.39 & 0.19 & 0.50 \\
age $=2.04 \cdot W_{\mathrm{O}}^{0.94}$ & 0.07 & 0.71 & 0.02 \\
\hline
\end{tabular}

$a=$ intercept value, $b=$ regression slope, $R^{2}=$ coefficient of determination, $\mathrm{SE}=$ standard error; $L_{\mathrm{O}}=$ otolith length, $B_{\mathrm{O}}=$ otolith breadth, $T_{\mathrm{O}}=$ otolith thickness, $W_{\mathrm{O}}=$ otolith weight.

1969a). According to Cohen (1958), the argentine is an example of the known tendency of certain fish species to respond morphologically to environmental influences, especially temperature as influenced by the latitude. The dominance of comparatively smaller individuals in the population size structure in our research could also be explained by the fishing gear selectivity (Wileman et al. 1996) or the sampling procedure, e.g. sampling depths and sampling time, as trawling was conducted only during the daylight hours. According to Carpentieri et al. (2005), A. sphyraena is a diurnal feeder, displaying individual feeding movements and therefore reducing its density and vertical availability to the net during the daylight. Moreover, bigger and older specimens of the argentine tend to live in deeper waters (Halliday 1969c).

The argentine females and males showed differences in growth, as females were larger than males at all ages sampled and this is in agreement with the result of Halliday (1969a). However, comparison of the growth parameters and mean lengths-at-age obtained by this study and by Halliday (1969a) revealed differences. While we reported that the value of $L_{\infty}$ is $17.57 \mathrm{~cm}$, this value, based on the standard length, is $19.0 \mathrm{~cm}$ for males and $20.0 \mathrm{~cm}$ for females in the Clyde Sea. In addition, mean lengths at ages 1-3 were smaller for the eastern Adriatic population. All observed differences can be related to different population size structures and/or different fishing pressures in the two areas. Regarding the fishing pressure, although there is no fishery targeting this species in both the Adriatic and the Clyde Sea, fishing mortality may be a significant part of the total mortality as Argentina sphyraena is very susceptible to damage, particularly through scale loss, so the survival of the discards is most unlikely (Halliday 1969a, Magnússon 1996). Moreover, we acknowledge that the sample size was relatively small for modelling growth and that more data, particularly from bigger and older specimens, would improve our estimates and ensure modelling for females and males separately.

Several studies have demonstrated that otolith size can be used as a proxy for otolith annuli counts in fish ageing (Pilling et al. 2003, Doering-Arjes et al. 2008, Steward et al. 2009, Matić-Skoko et al. 2011). The mean otolith length, breadth, thickness, and weight increased with age of Argentina sphyraena, implying that these morphometrics may provide a satisfactory method of ageing. Moreover, a power model described all relations between otolith morphometrics and fish age, and according to Škeljo et al. (2012), this model may be a result of the specific otolith growth rates of younger fish, as they dominated in our sample. The age of the argentine can be best predicted from the otolith thickness. However, we have to note that models did not provide very precise estimates and this could be explained by the overlap in lengths between fish of different age and only a few estimated age-groups. On the other hand, observed pentagonal otolith shape is specific for A. sphyraena and therefore can be used as a powerful tool in the identification of species and determination of fish prey identity in feeding studies, as this species is an important prey of many marine fishes and cephalopods (Bilge and Gülşahin 2014).

\section{REFERENCES}

Beamish R.J., Fournier D.A. 1981. A method of comparing the precision of a set of age determinations. Canadian Journal of Fisheries and Aquatic Sciences 38 (8): 982-983.

DOI: $10.1139 / \mathrm{f} 81-132$

Bilge G., Gülşahin A. 2014. Relationship between sagittal otolith size and fish size in Argentina sphyraena and Glossanodon leioglossus (Osteichthyes: Argentinidae) in the southern Aegean Sea, Turkey. Zoology in the Middle East 60 (1): 24-28. DOI: $10.1080 / 09397140.2014 .892327$

Bilge G., Yapıcı S., Filiz H., Cerim H. 2014. Weightlength relations for 103 fish species from the southern Aegean Sea, Turkey. Acta Ichthyologica et Piscatoria 44 (3): 263-269.

DOI: $10.3750 / A I P 2014.44 .3 .11$

Carpentieri P., Colloca F., Ardizzone G.D. 2005. Daynight variations in the demersal nekton assemblage on 
the Mediterranean shelf break. Estuarine, Coastal and Shelf Science 63 (4): 577-588.

DOI: $10.1016 /$ j.ecss.2005.01.005

Chang W.Y.B. 1982. A statistical method for evaluating the reproducibility of age determination. Canadian Journal of Fisheries and Aquatic Sciences 39 (8): 1208-1210.

DOI: $10.1139 / \mathrm{f} 82-158$

Cohen D.M. 1958. A revision of the fishes of the subfamily Argentininae. Bulletin of the Florida State Museum, Biological Sciences 3 (3): 93-172.

Cohen D.M. 1990. Argentinidae. Pp. 235-238. In: Quero J.C., Hureau J.C., Karrer C., Post A., Saldanha L. (eds.) Check-list of the fishes of the eastern tropical Atlantic (CLOFETA). JNICT, Lisbon, SEI, Paris, UNESCO, Paris.

Doering-Arjes P., Cardinale M., Mosegaard H. 2008. Estimating population age structure using otolith morphometrics: A test with known-age Atlantic cod (Gadus morhua) individuals. Canadian Journal of Fisheries and Aquatic Sciences 65 (11): 2342-2350. DOI: 10.1139/F08-143

Halliday R.G. 1969a. Distribution and regional variation of Argentina sphyraena [Pisces: Isospondyli]. Journal of the Marine Biological Association of the United Kingdom 49 (1): 189-208.

DOI: $10.1017 / \mathrm{S} 0025315400046518$

Halliday R.G. 1969b. Population parameters of Argentina sphyraena [Isospondyli] from west of Britain. Journal of the Marine Biological Association of the United Kingdom 49 (2): 407-431.

DOI: $10.1017 / \mathrm{S} 0025315400035992$

Halliday R.G. 1969c. Reproduction and feeding of Argentina sphyraena [Isospondyli] in the Clyde Sea Area. Journal of Marine Biological Association of the United Kingdom 49 (3): 785-803.

DOI: $10.1017 / \mathrm{S} 0025315400037292$

Hartel K.E., Orrell T.M. 2016. Argentinidae. Pp. 1751-1753. In: Carpenter K.E., De Angelis N. (eds.) The living marine resources of the Eastern Central Atlantic. Vol. 3: Bony fishes part 1 (Elopiformes to Scorpaeniformes). FAO Species Identification Guide for Fishery Purposes. FAO, Rome.

Kotthaus A., Krefft G. 1957. Fischfaunenliste der Fahrten mit F.F.S. „Anton Dohrn” nach Island - Grönland Mai/ Juli und September/Oktober 1955 einschließlich eines kleinen ostgrönländischen Materials bathypelagischer Fische, gesammelt von Dr. Hermann EinarssonReykjavik (Oktober 1954/Januar 1955). Berichte der Deutschen Wissenschaftlichen Kommission für Meeresforschung 14 (3): 169-191.

DOI: 10.2312/berichte_dwkfm_14_3_169-191

Lee J.Y. 1963. Les Argentines du Golfe du Lion, Argentina sphyraena L., Argentina leioglossa Val. Revue des Travaux de l'Institut des Pêches Maritimes 27 (2): 189-194.

Magnússon J.V. 1996. Greater silver smelt, Argentina silus in Icelandic waters. Journal of Fish Biology 49 (sA): 259-275.
DOI: 10.1111/j.1095-8649.1996.tb06080.x

Matić-Skoko S., Ferri J., Škeljo F., Bartulović V., Glavić K., Glamuzina B. 2011. Age, growth and validation of otolith morphometrics as predictors of age in the forkbeard, Phycis phycis (Gadidae). Fisheries Research 112 (1-2): 52-58.

DOI: 10.1016/j.fishres.2011.08.010

Mytilineou C., Politou C.-Y., Papaconstantinou C., Kavadas S., D'Onghia G., Sion L. 2005. Deep-water fish fauna in the eastern Ionian Sea. Belgian Journal of Zoology 135 (2): 229-233.

Muus B.J., Nielsen J.G. 1999. Sea fish. Scandinavian Fishing Year Book, Hedehusene, Denmark.

Petrić M., Ferri J., Škeljo F., Brčić J., Krstulović Šifner S. 2012. Histological analysis of the silver smelt, Argentina sphyraena (Pisces, Argentinidae) gonads during the spawning period. Pp. 170-170. In: XIV European Congress of Ichthyology, 3-8 July 2012, Liege, Belgium.

Pilling G.M., Grandcourt E.M., Kirkwood G.P. 2003. The utility of otolith weight as a predictor of age in the emperor Lethrinus mahsena and other tropical fish species. Fisheries Research 60 (2-3): 493-506. DOI: $10.1016 / \mathrm{S} 0165-7836(02) 00087-5$

Politou C.-Y., Mytilineou C., D'Onghia G., Dokos J. 2008. Demersal faunal assemblages in the deep waters of the eastern Ionian Sea. Journal of Natural History 42 (5-8): 661-672. DOI: $10.1080 / 00222930701835613$

Poll M. 1953. Poissons: 3. Téléostéens malacoptérygiens. Expédition océanographique belge dans les eaux côtières africaines de l'Atlantique Sud (1948-1949): résultats scientifiques. Institut royal des Sciences naturelles de Belgique, Bruxelles 4 (2): 1-258.

Schmidt J. 1918. Argentinidae, Microstomidae, Opisthoproctidae, Mediterranean Odontostomidae. Report on the Danish Oceanographic Expedition 1908-1910 to the Mediterranean and Adjacent Seas. Biology (Part A) 2: 1-40.

Steward C.A., DeMaria K.D., Shenker J.M. 2009. Using otolith morphometrics to quickly and inexpensively predict age in the gray angelfish (Pomacanthus arcuatus). Fisheries Research 99 (2): 123-129.

DOI: 10.1016/j.fishres.2009.05.011

Škeljo F., Ferri J., Brčić J., Petrić M., Jardas I. 2012. Age, growth and utility of otolith morphometrics as a predictor of age in the wrasse Coris julis (Labridae) from the eastern Adriatic Sea. Scientia Marina 76 (3): 587-595.

DOI: $10.3989 /$ scimar.03521.07G

Wileman D.A., Ferro R.S.T., Fonteyne R., Millar R.B. 1996. Manual of methods of measuring the selectivity of towed fishing gears. ICES Cooperative Research Report No. 215.

Received: 23 June 2017

Accepted: 20 October 2017

Published electronically: 31 December 2017 